\title{
Changes in the International System: The Pacific Basin
}

\author{
By LAWRENCE B. KRAUSE
}

\begin{abstract}
The economies of the Pacific Basin have been much more successful than those in other areas during the 1980s. Economic growth in the Pacific has been high and inflation has been well contained. Five factors seem to be most important in explaining this success. First, these economies have managed to form a consensus to promote growth rather than other societal goals. Second, the people work very hard. Third, they save and invest an unusually large share of their current incomes. Fourth, they implement market-conforming economic policies that are particularly outward looking. Finally, these economies benefit from a regional factor that comes from being surrounded by other successful countries. Leadership in the Pacific Basin has been supplied only by the United States; however, Japan has taken on a more prominent role in recent years and may become dominant in the future.
\end{abstract}

Lawrence B. Krause received both his bachelor's and master of arts degrees from the University of Michigan and his Ph.D. from Harvard University in 1958. He was the first professorial appointment to the new Graduate School of International Relations and Pacific Studies at the University of California at San Diego and joined the faculty on 1 January 1987. Previously he was a senior fellow of the Brookings Institution. Among his publications is The Singapore Economy Reconsidered, coauthored with Koh Ai Tee and Lee (Tsao) Yuan (1987). 
T HE variance in economic performance 1 between different areas of the world in the 1980s is remarkable, as shown in Table 1. Observers of Latin America refer to this decade as one of crisis from beginning to end. The economic situation of most African countries deteriorated from an already minimal standard of living. While there was stirring in Europe toward the end of the 1980s, most of the decade was characterized by stagnation and high unemployment, above 10 percent. By way of contrast, some economic progress was made in North America, albeit at the cost of creating a structural cconomic problem in the United States. Most striking of all, however, was the rapid economic advance made by the developing countries in the Pacific Basin, defined here as the 14 economies that participate in the Pacific Economic Cooperation Conference.

The economic achievement of the Pacific Basin is shown in Table 2. The picture that emerges is one of continuing economic prosperity during the 1980 s. The 1980 s in fact compare very favorably to the economic progress made in the previous two decades. Inflation rates have tended to be lower than in the 1970s, and economic growth of the newly industrializing economies has been at a peak level. The Pacific Basin has not been immune to the disturbances affecting the world economy, however, so that every country in the region has suffered from some sort of slowdown or recession at some point during the 1980s. Nevertheless, these economies recovered from the second oil shock and its aftermath, and they resumed rapid growth.

What accounts for this success compared to that of countries in other regions? First should be noted a few factors that were not responsible. The decline of rawmaterial prices - the so-called terms of trade shock - that inhibited natural-resource exporters in Latin America and Africa also afflicted the natural-resource exporters of the Association of Southeast Asian Nations, yet these countries performed much better. Also Korea, the Philippines, and Indonesia were major debtor countries at the start of the decade, but only in the case of the Philippines is external debt seen as a serious constraint on growth, and then only along with other, more important problems. The differences in economic performance must be found elsewhere, that is, not in the external environment, although the external environment was at least benign in the Pacific.

The answer to why the economic performance of the Pacific Basin has been better can be attributed to factors internal to each country and to the intense economic interaction between countries in the Pacific. One factor of great importance is the societal commitment to growth in each country. This means that it was possible to form a political consensus to make shortrun sacrifices to promote long-term growth. This has permitted these countries to react faster to external shocks than other countrics. A second factor was the willingness of people to work hard. While the number of working hours in a typical week, the number of holidays per year, and the like differ greatly from country to country, in general, the people in the Pacific work longer and possibly more intensively than people elsewhere.

High savings rates and high domestic investment rates found in Pacific Basin countries constitute a third factor helping to explain their success. Fourth, governments in the region tended to implement market-conforming economic policies. One strong characteristic of these policies has been their outward orientation, made 
TABLE 1

ECONOMIC PERFORMANCE AROUND THE WORLD

\begin{tabular}{lcc}
\hline & $\begin{array}{c}\text { Percentage Change in Real Gross Domestic Product } \\
1973-80\end{array}$ & $1980-87$ \\
\hline Industrial countries & 2.1 & 1.9 \\
Developing countries & 3.2 & 1.8 \\
Exporters of manufactures & 4.0 & 4.6 \\
Highly indebted countries & 2.9 & -1.3 \\
Sub-Saharan Africa & 0.5 & -2.9 \\
\hline
\end{tabular}

SOURCE: World Bank, World Development Report 1988 (Washington, DC: World Bank, 1988), p. 2.

TABLE 2

ECONOMIC PERFORMANCE IN THE PACIFIC BASIN DURING THE 1980s

\begin{tabular}{lcccr}
\hline \hline & \multicolumn{4}{c}{ Growth Rate of Real Gross Domestic Product } \\
& $1981-85$ & 1986 & 1987 & $1988 \mathrm{e}^{*}$ \\
\hline $\begin{array}{l}\text { Newly industrializing countries } \\
\text { Hong Kong }\end{array}$ & 5.8 & 11.8 & 13.5 & \\
Korea & 7.6 & 11.7 & 11.1 & 11.4 \\
Singapore & 6.5 & 1.8 & 8.8 & 10.9 \\
Taiwan & 6.2 & 10.6 & 12.4 & 7.1 \\
China & 9.3 & 7.9 & 10.1 &
\end{tabular}

Association of Southeast Asian

Nations (minus Singapore)

$\begin{array}{lrrrr}\text { Indonesia } & 3.5 & 4.0 & 3.6 & 4.7 \\ \text { Malaysia } & 5.5 & 1.2 & 4.7 & 7.9 \\ \text { Philippines } & -0.5 & 1.1 & 5.9 & 6.6 \\ \text { Thailand } & 5.6 & 3.4 & 10.4 & 11.0\end{array}$

Industrialized countries

$\begin{array}{llllr}\text { Australia } & 3.0 & 2.0 & 4.1 & 4.0 \\ \text { Japan } & 2.3 & 2.4 & 3.8 & 5.2 \\ \text { New Zealand } & 3.2 & 1.0 & 1.9 & -2.3 \\ \text { United States } & 2.4 & 3.3 & 3.5 & 3.8\end{array}$

\begin{tabular}{lcccc}
\hline & Percentage Change in Consumer Prices \\
& 1985 & 1986 & 1987 & $1988 \mathrm{e}^{\star}$ \\
\hline
\end{tabular}

Newly industrializing countries

$\begin{array}{lrrrr}\text { Hong Kong } & 3.2 & 2.8 & 5.5 & 7.5 \\ \text { Korea } & 2.5 & 2.8 & 3.0 & 7.1 \\ \text { Singapore } & 0.5 & -1.4 & 0.5 & 1.6 \\ \text { Taiwan } & -0.2 & 0.7 & 0.6 & 1.4 \\ \text { China } & 6.0 & 8.8 & 6.0 & 7.3\end{array}$


TABLE 2 continued

\begin{tabular}{|c|c|c|c|c|}
\hline & \multicolumn{4}{|c|}{ Percentage Change in Consumer Prices } \\
\hline & 1985 & 1986 & 1987 & $1988 e^{\star}$ \\
\hline \multicolumn{5}{|c|}{ Association of Southeast Asian } \\
\hline \multicolumn{5}{|c|}{ Nations (minus Singapore) } \\
\hline Indonesia & 4.7 & 5.9 & 9.3 & 8.9 \\
\hline Malaysia & 0.3 & 0.7 & 1.1 & 3.5 \\
\hline Philippines & 23.1 & 0.8 & 3.8 & 8.8 \\
\hline Thailand & 2.4 & 1.8 & 2.5 & 3.8 \\
\hline \multicolumn{5}{|c|}{ Industrialized countries } \\
\hline Australia & 6.7 & 9.1 & 8.5 & 7.2 \\
\hline Japan & 2.0 & -0.2 & 1.1 & 0.5 \\
\hline New Zealand & 13.0 & 18.3 & 9.0 & 13.4 \\
\hline United States & 3.5 & 1.5 & 3.6 & 4.1 \\
\hline
\end{tabular}

SOURCES: Official national income data; U.S. National Committee for Pacific Economic Cooperation, Pacific Economic Outlook, 1989-1990 (San Francisco: U.S. National Committee for Pacific Economic Cooperation, 1989).

*The figures for 1988 are estimates.

possible by the benign external environment. Finally, there is something that could be called a regional effect, that is, an intangible bonus that comes from being surrounded by other successful countries. The remainder of this article is devoted to an elaboration of some of these factors.

\section{SAVINGS AND INVESTMENT BEHAVIOR}

Economists interested in development have long moved away from models and theories that explain growth only on the basis of rates of capital investment. Clearly, many factors are important to the complex social phenomenon that results in economic advance. Furthermore, huge amounts of capital investment can and have been wasted in countries where capital markets were distorted or where politics dictated the allocation of new investment. Indeed, in such economies large investment shares did not lead to rapid growth. Nevertheless, investment does matter, and particularly that investment financed by domestic savings.

Some evidence of savings and investment behavior of Pacific countries is shown in Table 3. Category averages have been included to aid comparisons; categories are those used by the World Bank. An interesting difference can be noted between the share of gross savings in gross domestic product in 1965 and in 1986. In 1965 , four of the nine developing countries in the region had savings rates below the average of their category, one was the same, and only four were higher. By 1986, however, seven of the nine countries were above average and generally substantially above the average of the category. The only two exceptions in 1986 were Hong Kong and the Philippines, which was subject to political disruption, but subsequently the savings rate there has risen along with economic recovery.

It is not patently obvious why high domestic savings should be so growth promoting. Of course, investment requires 
TABLE 3

GROSS DOMESTIC INVESTMENT AND GROSS DOMESTIC SAVINGS AS A PERCENTAGE OF GROSS DOMESTIC PRODUCT

\begin{tabular}{|c|c|c|c|c|}
\hline \multirow[t]{2}{*}{ Category and Country } & \multicolumn{2}{|c|}{$\begin{array}{l}\text { Gross Domestic } \\
\text { Investment }\end{array}$} & \multicolumn{2}{|c|}{$\begin{array}{c}\text { Gross Domestic } \\
\text { Savings }\end{array}$} \\
\hline & 1965 & 1986 & 1965 & 1986 \\
\hline Low-income economies & 20 & 29 & 17 & 25 \\
\hline China & 25 & 39 & 25 & 36 \\
\hline \multicolumn{5}{|l|}{ Lower-middle-income } \\
\hline economies & 17 & 19 & 16 & 17 \\
\hline Indonesia & 8 & 26 & 8 & 24 \\
\hline Philippines & 21 & 13 & 21 & 19 \\
\hline Thailand & 20 & 21 & 19 & 25 \\
\hline \multicolumn{5}{|l|}{ Upper-middle-income } \\
\hline economies & 23 & 24 & 23 & 26 \\
\hline Hong Kong & 36 & 23 & 29 & 27 \\
\hline Korea (ROK) & 15 & 29 & 8 & 35 \\
\hline Malaysia & 20 & 25 & 24 & 32 \\
\hline Singapore & 22 & 40 & 10 & 40 \\
\hline Taiwan & 23 & 17 & 20 & 38 \\
\hline \multicolumn{5}{|l|}{ Industrial market } \\
\hline economies & 23 & 21 & 23 & 21 \\
\hline Australia & 28 & 22 & 26 & 21 \\
\hline Canada & 26 & 21 & 26 & 22 \\
\hline Japan & 32 & 28 & 33 & 32 \\
\hline New Zealand & 28 & 23 & 26 & 24 \\
\hline United States & 20 & 18 & 21 & 15 \\
\hline
\end{tabular}

SOURCE: World Bank, World Development Report 1988, pp. 230-31.

savings, but they need not be domestic savings. Domestic investment can be financed from abroad through foreign aid, borrowing, and foreign direct investment (FDI). Indeed, since the essence of industrial growth of developing countries involves increasing technological sophistication, and since FDI usually brings technology transfers from abroad, FDI could well be more growth promoting than an equivalent amount of investment financed by domestic sources. Nevertheless, the lesson that can be drawn from the experience of the Pacific Basin is that domestic savings capacity is crucial.
The main reason why domestic savings are so important is that they permit a high level of domestic investment without incurring foreign debt. As the Latin American experience demonstrates, foreign debt can turn out to be much more difficult to service than was anticipated at the time it was undertaken. Even concessional foreign borrowing can be burdensome if, as in the case of Indonesia, it is denominated in a currency, such as the yen, that is appreciating and the country's exports are priced in a depreciating currency. The gain from financing domestic investment from domestic savings may also arise in part from 
the automatic containment of inflation if consumption is self-constrained. In any event, the savings rate did rise rapidly in the developing countries of the Pacific Basin and economic growth did accelerate.

If domestic savings are crucial for growth, can the domestic savings rate be a direct target of government policy? It is sometimes argued in the United States that it cannot be manipulated directly, although macroeconomic management, the structure of taxes, and the like are believed to influence it. In most countries in the Pacific Basin, the savings rate has been an explicit target of policy. For example, Singapore has devised an elaborate Central Providential Fund to force a high rate of personal savings as part of a program to raise national savings. Japanese policy in earlier periods was aimed at suppressing domestic consumption to promote higher savings. Other examples could be cited. While cause and effect are difficult to document, comprehensive government programs to raise national savings rates and the achievement of that result are positively correlated.

As also seen in Table 3, the Pacific Basin economies with few exceptions display high investment shares compared to category averages. The advantage of high investment shares needs no elaboration. It may well be, however, that high investment and high savings come out of a joint decision process by domestic entrepreneurs and that it is the action of these entrepreneurs that helps explain economic success.

\section{OUTWARD-ORIENTED POLICY}

The outward orientation of the policy of the economies of the Pacific Basin is widely recognized, and some observers attribute a major share of their success to this factor. While only a subjective determination is possible, it may well be that its importance as usually analyzed is exaggerated but that, when seen in its full dimension, it is not fully appreciated.

Outward orientation is usually characterized by a country's policy toward international trade and FDI. It is certain that almost every developing economy in the region - and that now includes Chinaconsidered itself too small to develop in a closed market, and therefore expanding industrial production and exporting industrial products went hand in hand. For example, Korea could never capture economies of scale by producing manufactures only for the domestic market. Hence export promotion was at the very heart of industrial policy in these countries. This does not mean, however, that they endorsed or practiced free trade themselves, even though they advocated it for their trading partners. Rather, they instituted mercantilist policics, that is, they limited imports while promoting exports. This was the Japanese plan for development, which was seen as a successful model to emulate.

All of the developing countries in the region, with one exception, practiced import substitution(IS). The policy was based on the usual infant-industry argument. One consequence of IS is the nurturing and training of domestic entrepreneurs and permitting them to amass some risk capital. The exception, of course, was Hong Kong, which did not restrict imports; this is the exception that proves the rule. The origin of Hong Kong's entrepreneurs was Shanghai and Canton. The training and the amassing of capital that they needed were provided by China's trade restrictions be- 
fore they departed. Hence Hong Kong received the benefits of an IS policy without having to implement it.

Nevertheless, the practice of IS in the Pacific Basin has been different from that in other regions. Even at its peak, it was never as extreme as elsewhere. In some places, such as Malaysia and Singapore, it was very mild indeed. Furthermore, it seems to have ended sooner in the process of development. Nevertheless, it still persists, and rather restrictive import regimes are still found in Indonesia, the Philippines, and, until quite recently, Korea. The major point of difference, however, was the focus in the region on promoting exports rather than restricting imports per se. Thus generous exceptions from import barriers were permitted when their existence directly threatened exports.

Policies toward FDI have differed greatly between the countries in the region. During its period of rapid industrial growth, Japan made it very difficult for foreign firms to undertake equity investments. Korea emulated Japanese policy, but not so vigorously. By way of contrast, Hong Kong never made a distinction between domestic investment and FDI, and Singapore has actively encouraged investment by multinational corporations (MNCs). During the latter 1980s, FDI has been particularly important in the rapid growth of Thailand and, to a lesser extent, Malaysia. This would not have been possible if restrictive policies had been in place. Ironically, the goal of policy in countries that promoted FDI, such as Singapore, was not much different from that in Korea, which closely regulated it. In both cases, the purpose was to promote exports. Since the Singapore market was too small to be of much interest to MNCs, if they invested in Singapore, it must have only been for the purpose of exporting most of the output. Sim- ilarly, Korea regulated FDI for the purpose of ensuring that a major component of output would be exported directly or indirectly.

The same variance in policy is seen with respect to other kinds of international capital flows. For example, Hong Kong freely permits capital flows in and out of the territory, while Korea still does not permit foreigners to make portfolio investments directly into its stock market or buy real estate. In general, it can be said that currentaccount items - goods and services - have been treated more liberally than capitalaccount items throughout the region.

An important point to recognize, however, is that outward orientation goes beyond policies dealing with trade and foreign investment. The economies in this region give constant attention to more successful countries for the purpose of learning from their experience. This has been described as the "flying-goose" pattern of development, in which followers mimic the leaders and try to catch up to them. The search is for a successful pattern that then can be adapted for domestic use. Both the copying and the adapting are important in this process. It is this larger sense of outward orientation that is not frequently appreciated and that provides the regional bonus of being located in a group of successful countries.

\section{DIRECT PARTICIPATION OF GOVERNMENTS}

The participation of governments in the process of economic development in the region is sometimes misunderstood. The difficulty occurs because a distinction is not drawn between market-distorting activities of government and the intrusiveness of government in general. It is true that there is much less market-distorting activ- 
ity in this region, but this should not be interpreted as the practice of laissez-faire, except in Hong Kong. Singapore is a perfect illustration of the point. The government of Singapore does not distort markets, but it is very intrusive in running the economy. The purpose of this government activity is not to replace the market but to make the market work better and faster. An expression of this in the United States would be an active and intrusive antitrust policy.

Governments in the Pacific Basin do many things to guide the market, and if successful, without distorting it. A major area of government participation has been as an entrepreneur in state-owned enterprises (SOEs). Generally, the rationale has been that the capital requirement and/or the risk is too great for private entrepreneurs, or simply that private enterprise did not choose to undertake the activity and government has moved in to fill the vacuum. At different times SOEs have loomed very large in the economies of Korea, Malaysia, Singapore, and Taiwan. Recently, some privatization has occurred, and more is talked about. Privatization has advanced not because government activity was deemed to be illegitimate but rather because, like the POSCO steel complex in Korea, it has achieved maturity, earned considerable profits, and no longer nceds government participation.

A second major activity of governments in the region has been the promotion of science and technology in industry. Governments have recognized the critical role of technology in industrial growth and have been prepared to give the market some encouragement to push the process along. Major efforts have been made in education. Indeed, once universal literacy was achieved, the mastering of technical skills was given top priority. At first that meant sending students abroad to study. Subsequently, domestic facilities were created. Taiwan has been most active in this regard. Frequently, government laboratories were created to promote scientific work and even to do contract research for business that the firm was incapable of doing itself. Government institutes have been formed to provide a clearinghouse for technical information for business. Korea has extensively utilized such organizations. In Singapore many SOEs operate in advanced technical areas, and MNCs are encouraged to bring high technology to the country. Finally, practically all of the countries give encouragement to research and development and to technical training through special tax provisions.

Some governments in the region were even more involved in directing their economies. In the 1970s, Korea's development plans were used to direct private investment decisions. The government provided subsidized loans to firms if they would follow the government's suggestions. Furthermore, in Singapore and Korea the government became involved in wage setting for the economy. Another illustration of government involvement is in Malaysia, where the distribution of income and wealth has been a major target of policy. All of these cases depict activist governments.

How much of the economic success of these countries can be attributed to activist policies is a matter of dispute. When they were successful, they did not distort markets, but mistakes were made. In the later 1970 s, Singapore restricted wage growth too intensively and created a labor shortage. To correct the shortage, wages were pushed up too rapidly, which contributed to a loss of competitiveness. In Korea in the 1970 s, too much incentive was given for 
investment in heavy and chemical industries and as a result, overcapacity was created, losses were made by operating firms, and loans went into default. These mistakes were unusual, however. Most of the time the economies performed quite well and were assisted by policy measures.

As economies grow larger, however, it becomes increasingly harder to design policy that is intrusive, not market distorting, and helpful for growth. Larger economies are necessarily more complex. It becomes increasingly difficult for governments to have the information necessary for sound decisions. Allocative decisions are better made by private economic agents with direct interest in the outcomes and closer to markets. Hence there has been a move toward liberalization of government regulations, along with a pulling back of direct governmental economic involvement in recent years.

\section{THE ROLE OF THE UNITED STATES AND JAPAN}

The flying-goose pattern of development in the Pacific Basin requires a leader to point the way. For most of the postwar period, that position was clearly filled by the United States. It was the United States that provided the technology that was transferred to others. It was to American universities that students went to study science, engineering, and social science as well. It was U.S.-based MNCs that made direct investments in the region, which forged organic links not only back to the United States but also to third countries in the region. It was the U.S. government that provided direct aid-at times in large amounts - to other governments, such as to Japan, Korea, the Philippines, Taiwan, and Thailand. It was U.S. foundations that supported training and research in and about the region. It was the United States, through its support of international institutions such as the World Bank and the General Agreement on Tariffs and Trade, that provided resources and an inviting external environment.

Possibly the greatest contribution that the United States made to the success of countries in the region was through having an open market that absorbed huge volumes of imported manufactures, permitting the success of an export-led growth strategy. In addition, U.S. power was critical in defining and stabilizing the political and security dimensions of the region.

The apex of American relative economic power was reached rather early in the postwar period. As European countries recovered from the war, and Japan not only recovered but entered a period of unparalleled economic acceleration, the relative position of the United States declined. The decline was speeded by U.S. involvement in Vietnam; however, in the 1970s, no other country was in position to challenge U.S. leadership. This changed in the 1980s as a result of U.S. policy choices and further acceleration of growth in the Pacific.

In the 1980s the United States no longer is the richest industrial country. When measured on a per capita basis in terms of international purchasing power-current exchange rates - the income level of Japan and several European countries has surpassed that of the United States. The United States has begun to run a huge imbalance of trade, the value of imports becoming much greater than the value of exports. In order to finance this deficit, the United States annually has to borrow large amounts abroad. The cumulation of this borrowing has quickly turned the United States into the world's largest debtor where previously it was the largest creditor. 
The competitor for economic leadership in the Pacific Basin is Japan. Even in the 1960 s, the Japanese model for development was being emulated in the region. Furthermore, Japan has long been the primary market for natural-resource goods produced in the region, hence the strong link between Australia and Japan. Moreover, Japanese firms rather early began to invest abroad for various purposes, relying upon the information channels of the general trading companies (sogo shosha). The Pacific Basin was the natural recipient of much of this investment. Recognizing its special role in the Pacific, Japan became the principal sponsor and force within the Asian Development Bank.

By the 1980s, Japanese business firms had begun to be recognized as world leaders. Where earlier they were known to be particularly competitive in heavy industries such as steel and shipbuilding, this competitiveness was explained in terms of greater capital investment. Now Japanese firms excel in high-technology industries. While the total size of the Japanese economy is smaller than that of the European Community or the United States, its industrial organization is also more concentrated. Hence the leading firms in Japan are at least the equal of those in other countries. It is Japanese management practices that are being studied intensively and being emulated everywhere. Since the appreciation of the yen, Japanese MNCs have been making large investments throughout the region and particularly in the United States. In some places, such as Thailand, Japanese firms dominate the scene. In many industries and in many countries, the goose leading the flock is Japanese.

With the shift in economic policy toward domestic-oriented growth in the late 1980 s, Japanese markets are being opened to the imports of manufactured goods, and most of them are coming from Pacific Basin countries. Between 1985 and 1988, Japanese imports of manufactured goods increased by 80 percent, as measured in dollars. Korean exports have grown particularly fast in this market. Some of these goods are produced by Japanese FDI in several countries. Hence at the margin, Japan is already replacing the United States.

It is in the financial area, however, that Japanese relative power is the greatest. As a result of high domestic savings rates combined with a high level of income, the potential for Japanese investment is unmatched. Japanese institutions such as banks and insurance companies that perform the financial intermediary function have become so large as to dwarf their foreign competitors.

During the 1980s, Japan has developed almost as large a balance-of-payments surplus as the United States has developed a deficit. This surplus has been invested primarily in U.S. securities but in other foreign assets as well. Japan is clearly the largest source of foreign capital in the world.

Until recently Japan has been reluctant to take a visible leadership position in the Pacific Basin, but that is beginning to change. Japan has recently become the largest giver of foreign aid. The Japanese have become more willing to offer their own ideas for the solution of regional or even world problems. For example, the Japanese put forth a plan to deal with the debt problem of the less developed countries. Japan has also taken upon itself to become the spokesperson for the interest of Pacific countries in the annual summit meeting of industrial countries. Given Japan's relative economic power, a further evolution in the direction of assuming leadership should be expected. 


\section{FUTURE PROSPECTS}

Given uncertainties in all dimensions, true forecasting of major economic developments is close to worthless. Nevertheless, it is interesting to extrapolate existing trends to form a naive scenario of future prospects. Two trends will be assumed to continue: the relative economic success of the Pacific Basin and the rise of Japanese leadership.

The examination of the forces promoting relative economic success in the Pacific Basin yields systemic explanations that need not be terminated. Their applicability could spread from one country to another in the region. Indeed, if the Pacific were believed to have discovered the key to economic success, then emulation might take place in other regions. What would this mean? There would be a resurgence of the classical virtues of saving and investing for the future. There would be a new reluctance by governments to distort markets. The importance of international trade would be enhanced. Activist governments would gear their policy toward export promotion. The consequence might well be the multiplication of large private enterprises with a global focus.

The further enhancement of Japan's economic leadership might mean that the modalities by which business is conducted in Japan would determine the nature of international regimes, just as the trade system of the 1950s and 1960 s reflected the United States. The international trade of Japan is managed by a handful of large firms (keiretsu) in a cooperative and collaborative relationship with the government, namely, with the Ministry of International Trade and Industry. Other countries have found that they need similar business firms and relationships to compete and negotiate with the Japanese. Hence a new era of rapidly expanding but managed international trade might emerge.

The financial strength of Japan must in time be reflected in the institutions and practices of the marketplace. International commerce, especially in the Pacific, will become increasingly dependent on Japanese financing. Japanese financial institutions have a natural advantage in obtaining access to yen. Thus the competitive position of Japanese institutions will be enhanced by increasing the international role of the yen, and they can be expected to promote such usage. There is every reason to expect that they will be successful. In fact, there is a strong possibility that the world will accept the yen as its key currency, replacing the dollar. Key-currency status is not determined by the issuer of a currency but by its foreign users. If traders and investors earn most of their income in yen and must make payment in yen, then the yen will become the unit of account, the transaction currency, and the choice for reserve accumulation.

Nothing has been said in this article about Europe, and clearly the movement toward closer integration within the European Community by 1992 is a major development. What if Europe is unwilling to accept the Pacific Century under Japanese leadership? After all, the major motivation for 1992 is to strengthen European competitiveness so as not to be dominated by the United States and Japan. Europe could react to the competitive challenge of the Pacific by turning inward and erecting barriers to the outside world.

European exclusiveness, should it occur, would likely be met by some sort of regional development in the Pacific. Unlike earlier decades after World War II, when security concerns prevented an economic schism between nonsocialist countries, the relaxation of tensions between the 
military superpowers is likely to permit more diversity of economic relations. The fact that the world would split up into regional blocs does not mean that they would necessarily be aggressive toward one another. Indeed, there would be great economic and political incentive to avoid con- flict. Nevertheless, there would be legal and practical distinctions between members and nonmembers. The Pacific bloc under Japanese leadership would be prosperous and dynamic, and very attractive to many countries. 